\title{
PENGENALAN SITUS WEBSITE DALAM PENGEMBANGAN BUDAYA LITERASI PONDOK PESANTREN AL-MARKAZ KAMPUNG SETU DESA SAMBILAWANG KECAMATAN WARINGINKURUNG SERANG
}

\author{
Endah Mawarny 1 \\ Abu Bakar Djafar ${ }^{2}$ \\ Ahmad Yani Nasution ${ }^{3}$ \\ Yenni Merinatul Hasanah4 \\ Yunus $^{5 *}$ \\ 1,2,3,4,5 Universitas Pamulang, Banten, Indonesia \\ nurhang542@gmail.com ${ }^{5 *}$
}

Kata Kunci:

[Literasi,

Membaca,

Pesanter]

Published by:

Abstrak: Peraturan pemerintah menunjukkan bahwa Gerakan Literasi Pesantren sangat penting untuk diterapkan di sekolah bahkan dipesantren. Gerakan Literasi Pesantren merupakan usaha yang dilakukan untuk membiasakan, mengembangkan, dan membelajarkan literasi secara komprehensif dan berkesinambungan. Implementasi Gerakan Literasi Pesantren di Pesantren Al-Markaz dapat dimulai dengan literasi dasar yaitu baca-tulis. Tujuan PKM untuk memperkenalkan situs-situs buku dan jurnal untuk meningkatkan literasi kyai, Pembina, santri. Dalam PKM metode analisis ini untuk isu kasus yang terdapat dalam fokus PKM dilakukan tahapan analisis lintas situs, artinya materi-materi yang dibutuhkan dapat digunakan/diperoleh literasi situs gooogle scholer dan pdfdriver untuk mendapat informasi isu kasus/hasil penelitian tentang isu yang dibutuhkan. Pertama, temuan penelitian Pondok Pesantren Al-Markaz Kampung Setu Desa Sambilawang Kecamatan Waringinkurung Serang. Temuan data dari pembiasaan dalam implementasi Gerakan literasi di Pondok Pesantren Al-Markaz Kampung Setu Desa Sambilawang Kecamatan Waringinkurung Serang, diperoleh temuan penelitian sebagai berikut: (1) penataan sarana dan prasarana literasi terus dikembangkan yang mencakup perpustakaan, pojok literasi sekolah dan area baca, (2) pemilihan bahan bacaan untuk literasi berupa buku fiksi dan non fiksi dengan bahasa bilingual, atau memuat dua bahasa dalam satu buku cerita, Kedua, memberikan situs-situs yang bisa digunakan untuk menambah keilmu salah satu google scholer dan pdf drive memuat informasi tentang pesantren dalam menguatkan literasi dalam membangun jiwa santri membaca.

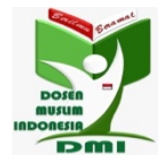

Copyright (C) 2021 The Author(s)

This article is licensed under CC BY 4.0 License

\section{(cc) Br}

https://dmi-journals.org/jai 


\section{Pendahuluan}

Membaca buku merupakan kegiatan yang mampu menambah kualitas diri dan menambah wawasan atas apa yang belum diketahui. Sama halnya dengan kata pepatah, buku adalah jendela dunia, dengan membaca buku apapun dapat diketahui. Namun, di masa pandemi seperti saat ini pemerintah menganjurkan untuk mengurangi aktifitas diluar rumah akibat adanya virus Covid-19. Keputusan tersebut berdampak pada KBM (Kegiatan Belajar Mengajar) yang sudah hampir dua tahun ini dilakukan secara daring/online baik bagi siswa, mahasiswa, maupun kalangan santri. Akibat dari daring sendiri membuat peserta didik lebih banyak bermain gadget dibanding membaca buku.

Peraturan pemerintah menunjukkan bahwa Gerakan Literasi Pesantren sangat penting untuk diterapkan di sekolah bahkan dipesantren. Gerakan Literasi Pesantren merupakan usaha yang dilakukan untuk membiasakan, mengembangkan, dan membelajarkan literasi secara komprehensif dan berkesinambungan. Implementasi Gerakan Literasi Pesantren di Pesantren Al-Markaz dapat dimulai dengan literasi dasar yaitu baca-tulis. Seperti yang telah diamanatkan dalam UU Sisdiknas pasal 4 tahun 2003 bahwa budaya membaca dilaksanakan untuk pendidikan. Berdasarkan sumber hokum negara Indonesia, maka disadari salah satu tugas pendidikan yaitu untuk meningkatkan kompetensi membaca dan mengembangkan budaya membaca siswa.

Menurut beberapa hasil penelitian dalam menyebutkan bahwa kegiatan membaca dapat menjaga kesehatan otak, meningkatkan kecerdasan logika dan linguistik sehingga santriyang rajin membaca akan cenderung lebih baik dalam memahami berbagai persoalan, baik yang berkaitan dengan mata pelajaran di sekolah maupun dengan kehidupannya sehari-hari. Membaca dipandang sebagai komponen penting untuk kesuksesan sekolah dan santrimembutuhkan kemampuan membaca yang bagus untuk memahami dan mempelajari materi yang beragam di kelas. Gerakan Literasi Pesantren dilaksanakan di pesantren mempunyai tujuan tersendiri, yaitu menumbuhkembangkan budaya literasi membaca dan menulis santridi sekolah, (2) meningkatkan kapasitas warga dan lingkungan sekolah agar sadar akan pentingnya budaya literasi, (3) menjadikan sekolah sebagai taman belajar yang menyenangkan dan ramah bagi siswa, dan (4) menghadirkan beragam buku bacaan dan mewadahi berbagai strategi membaca untuk mendukung keberlanjutan pembelajaran.

Program yang akan dilaksanakan atau akan diterapkan pasti mempunyai prinsipprinsip tertentu, demikian pula dengan program Gerakan Literasi Pesantren yang dicanangkan pemerintah mempunyai prinsip-prinsip. Pelaksanaan program Gerakan Literasi Pesantren mengacu pada prinsip (1) sesuai dengan tahapan perkembangan siswa, (2) dilaksanakan menggunakan berbagai ragam teks, (3) dilaksanakan secara terintegrasi dan holistic disemua area kurikulum, (4) dilakukan secara berkelanjutan, (5) melibatkan kecakapan berkomunikasi lisan, dan (6) mempertimbangkan keberagaman. Mengacu pada prinsip tersebut, adapun tahapan pelaksanaan Gerakan Literasi Pesantren dibagi ke dalam tiga tahapan, diantaranya tahap pembiasaan, pada tahapan ini, sekolah menyediakan berbagai buku dan bahan bacaan yang dapat menarik minat santridan melaksanakan kegiatan yang meningkatkan minat baca siswa. Peneliti kemudian melakukan studi pendahuluan berkaitan dengan Gerakan Literasi Pesantren di Pesantren Al-Markaz. 


\section{Metode Pelaksanaan}

Pengabdian ini dilakukan di Pondok Pesantren Al-Markaz Kampung Setu Desa Sambilawang Kecamatan Waringinkurung Serang. Temuan data dari pembiasaan gerakan literasi di Pondok Pesantren Al-Markaz Kampung Setu Desa Sambilawang Kecamatan Waringinkurung Serang,

Dalam analisis data dalam penelitian multisitus terbagi menjadi dua tahapan. Pada tahapan pertama peneliti akan melakukan analisis data situs tunggal, tahap ini bertujuan untuk menemukan temuan-temuan sementara dari masing-masing situs. Pada tahapan kedua akan dilakukan analisis data lintas situs untuk menganalisis data dari ketiga situs hingga dapat menarik suatu kesimpulan. Analisis dan pengumpulan data secara berulang dilakukan agar dapat mengembangkan pola deskriptif pada keseluruhan situs. Adapun langkah-langkah dalam melaksanakan analisis lintas situs dengan metode induksi analitik modifikasi yaitu (1) membuat definisi kasar, (2) menyatukan data yang sesuai, (3) memodifikasi atau memberikan penjelasan terhadap kasus baru yang ditemukan karena tidak sesuai dengan definisi awal, (4) mendalami kasus yang tidak sesuai dengan definisi sebelumnya, dan (5) membuat definisi terkait fenomena tersebut dan menjelaskannya kembali hingga mendapatkan keterkaitan yang bersifat umum.

Penggunakan metode analisis ini untuk isu kasus yang terdapat dalam fokus PKM. Melalui tahapan analisis lintas situs diharapkan dapat menghasilkan keterkaitan yang bersifat universal tentang implementasi Gerakan Literasi Pesantren tahap pembiasaan. Prosedur analisis situs tunggal dilakukan dengan pengumpulan data dan analisis data ketiga situs hingga menemukan temuan sementara pada masing-masing situs lalu dilanjutkan dengan memadukan ketiga temuan sementara tersebut menjadi temuan sementara antar situs. Kemudian dilakukan analisis data lintas situs. Prosedur analisis lintas situs akan dilakukan uji terhadap temuan-temuan di situs pertama dengan temuan situs kedua dan ketiga atau sebaliknya, sehingga menghasilkan temuan baru. Temuantemuan baru inilah yang akan menjadi temuan akhir yang dibentuk menjadi proposisiproposisi yang saling mendukung dari ketiga situs yang skan diusulkan menjadi teori subtantif tentang implementasi Gerakan Literasi Pesantren. Pengecekan keabsahan data melalui kriteria kepercayaan, keteralihan, ketergantungan, dan kepastian.

\section{Hasil dan Pembahasan}

Pada bulan Maret 2020, Menteri Kesehatan Republik Indonesia mengonfirmasi adanya kasus positive Covid-19 pertama di Indonesia sebanyak 2 orang. Jumlah pasien covid-19 semakin mengalami kenaikan hingga mencapai angka ratusan ribu pasien positif. Upaya penanganan dan pencegahan penyebaran covid-19 dilakukan oleh pemerintah melalui pelaksanaan protocol kesehatan, memakai masker, mencuci tangan dan menjaga jarak. Pemerintah juga memberlakukan PSBB (Pembatasan Sosial Berskala Besar) sebagai upaya untuk menekan penyebaran. Adanya PSBB dan pembelakuan aturan karantina menyebabkan dampak yang cukup besar terhadap berbagai bidang kehidupan, ndemisalah satu yang paling berdampak adalah bidang ekonomi dan pemasaran. Hampir semua pelaku usaha mengalami penurunan omset dan tidak sedikit yang kemudian macet dan gulung tikar.

Temuan situs akan memaparkan temuan penelitian dari setiap situs yaitu, (1) paparan data literasi buku, (2), dan paparan situs-situs buku (3) paparan data buku fiksi dan non-fiksi. 
Pertama, temuan penelitian Pondok Pesantren Al-Markaz Kampung Setu Desa Sambilawang Kecamatan Waringinkurung Serang. Temuan data dari pembiasaan dalam implementasi Gerakan literasi di Pondok Pesantren Al-Markaz Kampung Setu Desa Sambilawang Kecamatan Waringinkurung Serang, diperoleh temuan penelitian sebagai berikut:

1. Penataan sarana dan prasarana literasi terus dikembangkan yang mencakup perpustakaan, pojok literasi sekolah dan area baca, (2) pemilihan bahan bacaan untuk literasi berupa buku fiksi dan non fiksi dengan bahasa bilingual, atau memuat dua bahasa dalam satu buku cerita,

2. Membaca sebelum pembelajaran dilakukan dengan membaca buku di setiap kelas sebelum pembelajaran dimulai, kegiatan membaca dilakukan juga di luar kelas dengan seluruh santri pada hari jumat,

3. Lingkungan kaya teks ditunjukkan dengan teks bergambar bermuatan motivasi dan slogan-slogan yang terdapat di tembok sekolah dan di setiap koridor sekolah dan karya santriyang ditempel di mading sekolah, dan

4. Melibatkan publik yang mencakup orangtua murid dan perpustakaan daerah dalam pelaksanaan kegiatan literasi pesantren.

Kedua, memberikan situs-situs yang bisa digunakan untuk menambah keilmu salah satu google scholar (Lihat Gambar 1) memuat informasi tentang pesantren dalam menguatkan literasi dalam membangun jiwa santri membaca.

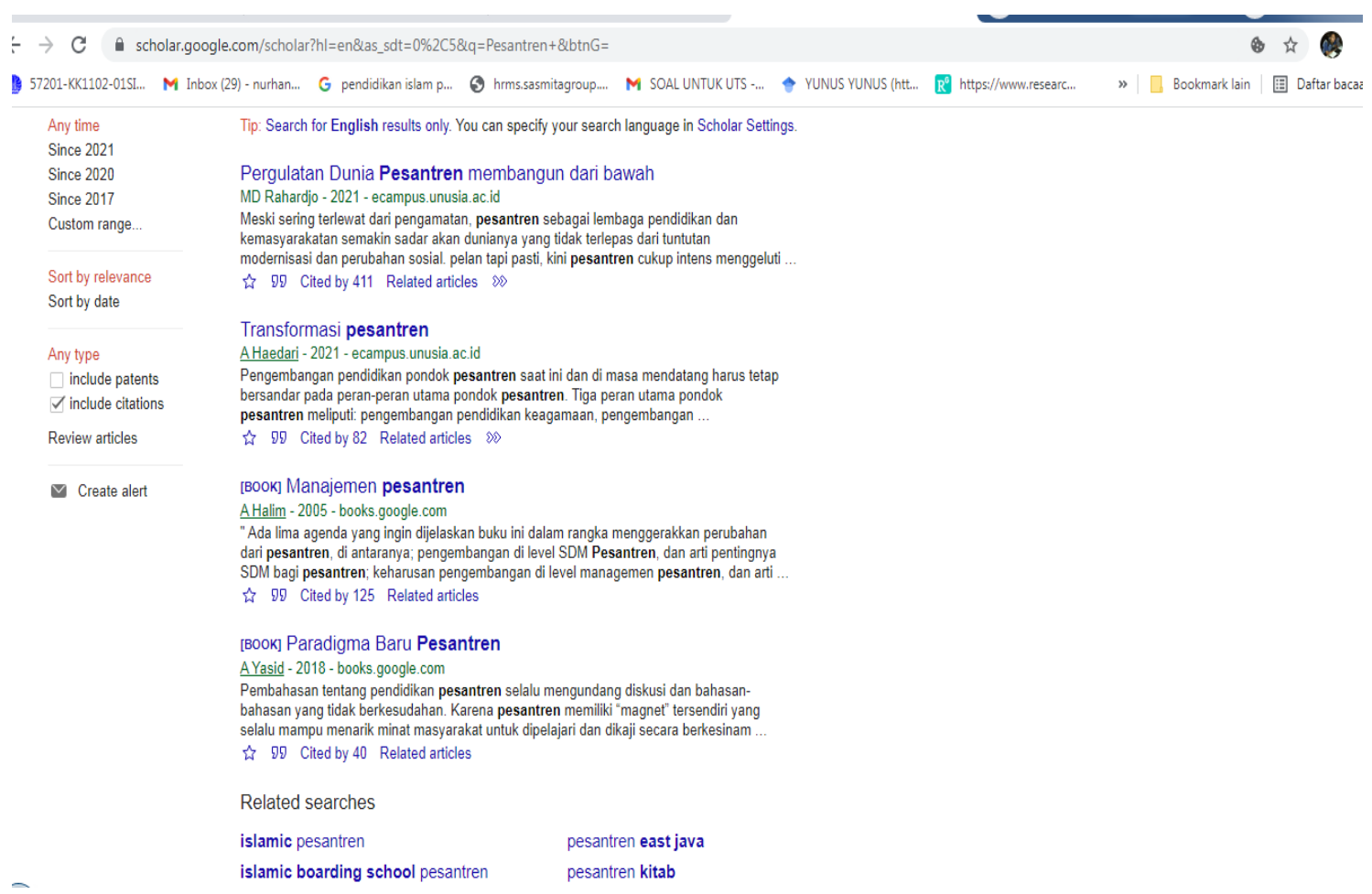

Gambar 1. Situs google scholer

Selain itu, situs lain yang bisa digunakan dalam menambah literasi buku, bisa digunakan situs pdf drive (Lihat Gambar 2), untuk menambah koleksi buku dalam literasi buku digital, website ini gratis untuk semua kalangan. 


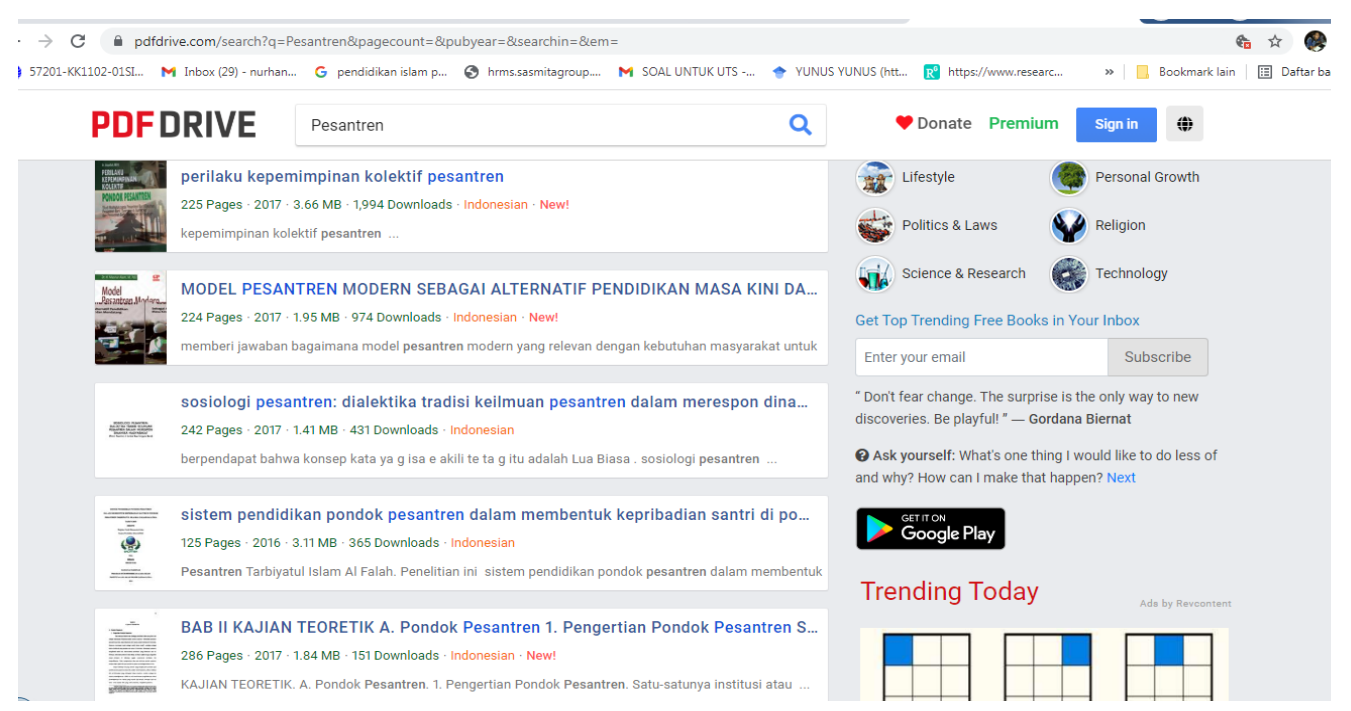

Gambar 2. Situs pdf drive

\section{Kesimpulan}

Dari kegiatan Pengabdian Kepada Masyarakat ini dapat diambil kesimpulan, bahwa penataan sarana dan prasarana literasi terus dikembangkan yang mencakup perpustakaan, pojok literasi sekolah dan area baca, pemilihan bahan bacaan untuk literasi berupa buku fiksi dan non fiksi dengan bahasa bilingual, atau memuat dua bahasa dalam satu buku cerita, serta dilengkapi situs-situs yang memuat literasi guna untuk menambah literasi kiai, guru, pembina, santri seperti google scholar dan pdf driver.

\section{Ucapan Terimakasih}

Penulis dengan segala kerendahan hati menyampaikan ucapan terima kasih kepada Bapak Dr. H. Sofyan Hadi Musa, M.Ag selaku Ketua Lembaga Kajian Keagamaan Universitas Pamulang. Bapak Adi selaku Pembina Pesantren Al-Markaz

\section{Referensi}

Azhar, R. K. D., Bashori, K., \& Samsuddin, M. (2020). PENANAMAN NILAI-NILAI PERDAMAIAN DI PEACESANTREN WELAS ASIH SAMARANG GARUT. Profetika: Jurnal Studi Islam, 21(2), 134-146.

Niam, Z. W. (2019). Membina Karakter Anak Melalui Program Full Day School Berbasis Nilai-Nilai Kepesantrenan (Studi Kasus di Madrasah Ibtidaiyah Nurul Ummah Kotagede Yogyakarta). BELAJEA: Jurnal Pendidikan Islam, 4(1), 19-34.

Qulloh, F. I. (2021). Pengembangan Literasi Dalam Peningkatan Minat Baca Santri Pada Perpustakaan Mini Pesantren Pelajar Al-Fath Rejomulyo Kediri. Jurnal Pengabdian kepada Masyarakat Nusantara, 3(1), 26-32.

Yunus, Y., Raharjo, S., Handayani, M., Arifah, N., Rafli, R., Sitepu, N., ... \& Saleha, W. I. (2021). THE ROLE OF SOCIAL MEDIA IN THE ERA OF DIGITAL TRANSFORMATION AS A 
Vol. 1. No. 3. November 2021

MEANS OF COMMUNICATION KARANG TARUNA COMMUNITY KAMPUNG PARUNG SERAB CILEDUG. International Journal of Engagement and Empowerment, 1(1), 1-5. 